\title{
O raspravnoj sposobnosti u forenzičnoj psihijatriji
}

\section{On competence to stand trial in forensic psychiatry}

\author{
Ante Periša $1^{*}$, Goran Arbanas ${ }^{2,3}$
}

\begin{abstract}
Sažetak. Raspravna je sposobnost pravni konstrukt koji podrazumijeva da okrivljenik shvaća svoj položaj u sudskom postupku, razumije procesne radnje i njihove posljedice, kao i da ima očuvane kapacitete za sporazumijevanje s braniteljem. Ukoliko ti kriteriji nisu zadovoljeni, okrivljenik se potencijalno nalazi u položaju koji je diskriminirajući. Radi zaštite jednog od temeljnih ljudskih prava - prava na pošteno suđenje, raspravna nesposobnost u današnjoj sudskoj praksi podrazumijeva odgodu sudske rasprave do oporavka raspravne sposobnosti. Po nalogu suda, sudski vještak psihijatrijske struke postaje osoba zadužena za pregled okrivljenika i procjenu njegovog trenutnog duševnog stanja. Budući da dobar forenzičar treba poznavati relevantne pravne dokumente i primjere iz sudske prakse, dan je kratki prikaz pravnih aspekata raspravne sposobnosti. Isto tako, budući da prisutnost duševne bolesti ne podrazumijeva odmah i raspravnu nesposobnost, dani su i psihijatrijski aspekti s naglaskom na česte psihopatološke fenomene s prediktivnom vrijednošću u proglašenju okrivljenika raspravno nesposobnim.
\end{abstract}

Ključne riječi: forenzična psihijatrija; psihopatologija; raspravna sposobnost

Abstract. The competence to stand trial is a legal construct that implies that a defendant understands their position during trial, comprehends court's proceedings and consequences, and has the sufficient capacity to communicate with their attorney. If these criteria are not met, the defendant will find him/herself in a potentially discriminating position. To protect one of the fundamental human rights - the right on a fair trial, the incompetence to stand trial presupposes trial delay until this competence is restored. By the court's order, a psychiatrist assesses a defendant's current mental state. Considering that a good forensic psychiatrist has to be familiar with the Criminal Code and cases from trial practice, a short view on legal aspects is given here. Moreover, as the diagnosed mental illness does not automatically presume incompetence to stand trial, psychiatric aspects with emphasis on the frequently occurring psychopathological phenomena with predictive value are given.

Key words: forensic psychiatry; mental compentence; psychopathology
${ }^{1}$ Sveučilište u Zagrebu, Medicinski fakultet, Zagreb, Hrvatska

${ }^{2}$ Sveučilište u Rijeci, Medicinski fakultet, Rijeka, Hrvatska

${ }^{3}$ Zavod za forenzičku psihijatriju „Dr. Vlado Jukić", Klinika za psihijatriju Vrapče, Zagreb, Hrvatska
*Dopisni autor:

Ante Periša, dr. med.

Sveučilište u Zagrebu, Medicinski fakultet

Šalata 2, 10000 Zagreb, Hrvatska

E-mail: ante.perisa1@hotmail.com 


\section{UVOD}

Forenzična je psihijatrija granično područje između psihijatrije i prava. Česta podjela djelokruga forenzične psihijatrije jest na forenzičnu psihijatriju koja se bavi pitanjima iz građanskog prava i na ona koja se odnose na kazneno pravo. $U$ ovom je radu riječ o raspravnoj sposobnosti - pitanju unutar kaznenog prava. Sposobnost se općenito odnosi na mogućnost razumijevanja određenog znanja i razumne primjene tog znanja u procesu

Procjena raspravne sposobnosti za svrhu ima zaštititi jedno od temeljnih ljudskih prava - pravo na pošteno suđenje, stoga neodržana raspravna sposobnost podrazumijeva odgodu sudske rasprave do oporavka raspravne sposobnosti.

donošenja odluka ${ }^{1}$. Poseban je oblik sposobnosti i raspravna sposobnost. Procjena raspravne sposobnosti za svrhu ima zaštitu prava okrivljenika na pošteno suđenje ${ }^{2}$. Vještačenje raspravne sposobnosti izvodi sudski vještak psihijatrijske struke po nalogu suda. Neki od razloga radi kojih sud često izdaje nalog za vještačenje raspravne sposobnosti jesu neobično ponašanje za vrijeme rasprave, aktualna duševna bolest, prethodne psihijatrijske hospitalizacije i sumnja na duševnu bolest zbog otežane suradnje s braniteljem ${ }^{3}$. Ipak, važno je napomenuti da sud može iz bilo kojeg razloga zatražiti vještačenje raspravne sposobnosti. Uz raspravnu sposobnost, u kaznenom se pravu još postavljaju pitanja poput psihičkog stanja tempore criminis - ubrojivosti, procjene opasnosti, odnosno prijedloga sigurnosne mjere. Pravilo je struke da psihijatrijski vještak i psihijatar terapeut ne budu ista osoba ${ }^{4}$. Time se želi osigurati što veća nepristranost vještaka. Za očekivati je da bi već postojeći terapeutski odnos mogao imati ometajuće djelovanje na vještaka prilikom donošenja mišljenja. S druge strane, prema hrvatskom zakonodavstvu liječnik vještak oslobođen je čuvanja liječničke tajne te je dužan sve relevantne informacije dobivene od ispitanika dostaviti sudu. To dovodi vještaka u poziciju u kojoj mora održati ravnotežu između normativa deontologije svog primarnog liječničkog poziva i pravne etike. Čuvanje temeljnih ljudskih prava duševnih bolesnika trebao bi biti imperativ svim psihijatrima i stručnjacima ostalih pomagačkih struka. Nažalost, o ovoj se temi malo govori, a još manje piše, stoga vjerujemo kako ovaj kratki pregled može potaknuti diskurs o zaštiti duševnog bolesnika u svim okolnostima, pa i u sudnici. Budući da je djelovanje forenzičnih psihijatara određeno okvirima pravnog sustava, dio rada, uz čestu psihijatrijsku fenomenologiju koja se veže uz raspravnu nesposobnost, govori i o pravnim aspektima raspravne sposobnosti.

\section{PRAVNI ASPEKTI RASPRAVNE SPOSOBNOSTI}

\section{Povijesni pregled}

Koncept raspravne sposobnosti spominje se još u 14. stoljeću u Engleskoj za vrijeme vladavine Edwarda I. kada se kod okrivljenika koji su na suđenju bili mutistični prepoznala razlika između onih koji su šutjeli namjerno (engl. muteness by "malice") i onih koji su bili mutistični zbog duševne bolesti (engl. muteness „by visitation of God") $)^{5}$. U novijoj povijesti prve psiholegalne kriterije potrebne za očuvanu raspravnu sposobnost daje Vrhovni sud Sjedinjenih Američkih Država u presudi Dusky v. SAD iz 1960. godine. Dusky kriteriji zahtijevali su da za suđenje okrivljenik treba imati očuvano razumijevanje sudskog procesa, kako faktičko tako i racionalno, kao i sposobnost suradnje s braniteljem u pripremi obrane ${ }^{3}$. Kriteriji su, uz poneke varijacije, bili implementirani u zakone svake države SAD-a ${ }^{6}$. Budući da pravni sustav svake države ima svoje specifičnosti, važno je istaknuti pojam raspravne sposobnosti u Republici Hrvatskoj kako je posredno definiran u čl. 325. st. 5. Zakona o kaznenom postupku iz 2011. godine, a koji pri ocjeni raspravne sposobnosti od vještaka traži da ustanovi ima li okrivljenik duševne smetnje i da iznese svoje mišljenje je li okrivljenik sposoban shvatiti prirodu i svrhu kaznenog postupka, razumjeti pojedine procesne radnje i njihove posljedice, sporazumijevati se s braniteljem i davati mu upute. Pravni kriteriji raspravne sposobnosti u Republici Hrvatskoj u skladu su s čl. 6. Europske konvencije za ljudska prava ${ }^{8}$ - Pravo na pošteno suđenje s naglaskom na stavak 3. koji propisuje minimalna prava svakog okrivljenika, a to su: pravo na informiranje razumljivim jezikom o prirodi i razlogu optužbi, pravo na prikladno vri- 
jeme i sredstva za pripremu obrane, pravo na obranu bilo samostalno bilo uz zastupanje odvjetnika i napose, pravo na ispitivanje svjedoka i pravo da se bude ispitan pod istim uvjetima.

\section{Pravni sustavi}

Za praksu vještaka psihijatra važno je istaknuti grubu podjelu pravnog sustava na anglosaksonsko pravo (engl. common law) i na europsko kontinentalno pravo (engl. civil law). Ipak, valja napomenuti kako postoje i ostale podjele koje uključuju običajno pravo, vjersko pravo, proceduralno pravo itd. Obilježje anglosaksonskog prava je i suparništvo koje podrazumijeva aktivniju ulogu okrivljenika ${ }^{9}$. Bonnie i Grisso procijenili su da se godišnje u Sjedinjenim Američkim Državama odradi 60000 ocjena raspravne sposobnosti ${ }^{10}$ koja je u usporedbi s prijašnjim procjenama ${ }^{11} \mathrm{u}$ toj državi pokazala i tendenciju rasta. S obzirom na tradiciju da se $u$ suparničkom pravu okrivljenik aktivnije brani i konfrontira sudionike sudskog postupka, za očekivati je da je broj evaluacija tamo veći. U europskom pravnom sustavu, pa i u Hrvatskoj, za očekivati je manji broj ocjena raspravne sposobnosti, i to zbog mješovitog kaznenog pravnog sustava koji sadrži elemente inkvizicijskog, ali i suparničkog sustava. Ipak, u Hrvatskoj podatci o broju ocjena raspravnih sposobnosti nisu dostupni. Van der Wolf i suradnici usporedili su dva sustava, suparnički sustav u Kanadi i inkvizicijski u Nizozemskoj ${ }^{12}$. Razlike se ogledaju u tome što se $u$ anglosaksonskom pravu naglašava natjecateljska dinamika u sudnici, što zahtijeva od obiju strana podjednak angažman, time i neupitnu raspravnu sposobnost okrivljenika. Primjera radi, u suparničkom sustavu vještaci mogu biti postavljeni i od branitelja i od tužitelja, što ponovno može dovesti do natjecanja u mišljenjima vještaka. U europskom pravu vještaka imenuje sudsko vijeće. Sudac također ima ulogu ispitivača, dok je ta uloga suca u anglosaksonskom pravu sporedna. Isto tako, u anglosaksonskom pravu postavljanje pitanja svjedocima unakrsno mogu izvoditi odvjetnici obiju strana, kao i stranke tih odvjetnika.

\section{Pravna zaštita raspravno nesposobnih okrivljenika}

Kazna za počinjeno djelo donosi i svojevrsnu obnovu društvu, što traži da okrivljenik razumije svrhu kazne i navedeno je u čl. 41. Kaznenog zakona ${ }^{13}$ koji za svrhu kazne navodi društvenu osudu, jačanje povjerenje građana u pravni poredak, utjecaj na počinitelja i sve druge da ne čine kaznena djela i reintegraciju pojedinca u društvo ${ }^{14}$. Ukoliko je okrivljenik raspravno nesposoban i ne razumije svrhu kazne, izostaju pozitivne implikacije kažnjavanja, kako za okrivljenika tako i za društvo. Uloga okrivljenika protiv kojeg se vodi sudski proces uvjetuje i vulnerabilniji položaj okrivljenika ${ }^{14}$. Upravo je vulnerabilnost posebno značajna u raspravno nesposobnih osoba koje nisu kompetentne shvatiti svoj položaj kao ni iznijeti adekvatnu obranu. Ipak, pojedini članci u Zakonu o kaznenom postupku kompenziraju njihovu ranjivu poziciju. Tako je člankom 223. st. 1. Zakona o kaznenom postupku ${ }^{7}$ propisano da državni odvjetnik u slučaju raspravne nesposobnosti okrivljenika uzrokovane zdravstvenim smetnjama rješenjem prekida istragu, dok čl. 406. u istom slučaju propisuje odgodu rasprave, osim ako je okrivljenik proglašen neubrojivim (čl. 552. st. 2.). Time se otvaraju pitanja mogućnosti zlouporabe instituta raspravne sposobnosti. Primjerice, okrivljenik koji ima propisanu psihijatrijsku terapiju može prestati uzimati terapiju u razdoblju prije održavanja rasprave kako bi se doveo u stanje raspravne nesposobnosti. S druge strane, institut mogu zloporabiti i sami vještaci ukoliko iz bilo kojeg razloga pogoduju ispitaniku na način da u svojem mišljenju proglase raspravnu nesposobnost u svrhu prekida istrage ili odgode rasprave do njezine obnove. I vještaci i ostali sudionici sudskog procesa trebaju biti svjesni i takvih mogućnosti.

\section{Raspravna sposobnost - ima li je ili nema?}

Raspravna sposobnost je u pravnom rječniku pojam koji ima samo dvije kategorije - ili postoji ili ne postoji. Prijelazni oblici nisu predviđeni zakonima. Radi usklađivanja s pravnim normama, vještak mora svoj klinički dojam o ispitaniku prevesti u jednu od dviju navedenih mogućnosti. Usporedbe radi, pri procjeni ubrojivosti okrivljenika postoje stupnjevi (ubrojiv; smanjeno ubrojiv, ali ne bitno; bitno smanjeno ubrojiv i neubrojiv). Međutim, vještaku sud može postaviti pitanje o obnovi raspravne sposobnosti i tražiti da ponudi 
prijedlog dopune vještačenja nakon određenog vremena, što je najčešće period od šest mjeseci6. Isto tako, vještak u svojoj ekspertizi može napisati napomenu o tzv. parcijalnoj raspravnoj sposobnosti koja podrazumijeva raspravnu sposobnost, ali pod prilagođenim uvjetima ${ }^{15}$, primjerice češće stanke tijekom rasprave. Krajnji su, ali ipak znatno rjeđi, slučajevi u kojima se proglašava trajna raspravna nesposobnosti. Takvu odluku opravdava trajno i progresivno propadanje ličnosti okrivljenika u sklopu kroničnih psihotičnih stanja ${ }^{16}$, premda je u hrvatskoj praksi takvo što puno češće kod onih ispitanika koji boluju od teške demencije ili težih stupnjeva intelektualne onesposobljenosti.

\section{Raspravna sposobnost svjedoka}

Vještačenje raspravne sposobnosti svjedoka nije predviđeno Zakonom o kaznenom postupku, ali se $u$ diskursu hrvatske forenzične psihijatrije razvila diskusija o tom pitanju. Folnegović-Šmalc, Henigsber i Folnegović-Grošić predlažu uvođenje mogućnosti vještačenja raspravne sposobnosti svjedoka u sljedećem ZKP-u ${ }^{17}$ čime bismo, kako se navodi, bili napredniji od ostalih europskih zemalja jer bi se time svaka potencijalna diskriminacija između okrivljenika, žrtve i svjedoka izbjegla. S druge strane, Goreta propitkuje logičnost takve ideje argumentirajući da vještačenje raspravne sposobnosti svjedoka i žrtve ne ide na korist žrtve ${ }^{16}$. Uzevši raspravnu sposobnost kao nužnu pri ostvarenju temeljnog ljudskog prava - prava na pošteno suđenje, jasno je od kolike je važnosti savjesno i odgovorno pristupiti vještačenju tog pitanja. Sudske prakse i pravni okviri unutar kojih vještaci psihijatrijske struke mogu obavljati vještačenja ponešto se razlikuju od države do države, dok su psihijatrijski kriteriji manje podložni varijabilnostima ovisno o državi u kojoj se vještačenje provodi.

\section{PSIHIJATRIJSKI ASPEKTI RASPRAVNE} SPOSOBNOSTI

Evaluacije raspravne sposobnosti nisu retrospektivne poput evaluacije ubrojivosti niti prospektivne poput procjene opasnosti, nego je naglasak na trenutnom psihičkom statusu okrivljenika, odnosno psihopatologiji koja onemogućuje okrivljeni- ka u sudjelovanju u glavnoj raspravi ${ }^{18}$. Duševna bolest svakako jest jedan od kriterija za raspravnu nesposobnost, ali to ne znači da bilo koja duševna bolest neovisno o postojećoj psihopatologiji utječe na raspravnu sposobnost ${ }^{18}$. Važno je prepoznati one psihopatološke fenomene, kao i kognitivna oštećenja koja direktno mogu utjecati na raspravu u sudnici. U metaanalizi Pirellija i suradnika iz 2011. godine dan je pregled dotadašnjih radova u kojima su se, između ostalog, istraživale korelacije raspravne nesposobnosti i demografskih, kriminoloških i kliničkih varijabli5 ${ }^{5}$ Demografske i kriminološke varijable pokazale su slabiju korelaciju s ishodom vještačenja, izuzev varijable nezaposlenosti. Takve su osobe imale dva puta veće izglede da budu proglašene raspravno nesposobne. Od kliničkih varijabli, dijagnoza je istaknuta kao najvažnija, napose dijagnoze iz skupine psihotičnih poremećaja koje su predviđale osam puta veće izglede za status raspravne nesposobnosti, dok se prethodne hospitalizacije i prethodna vještačenja raspravne sposobnosti nisu pokazali značajnima u predviđanju ishoda vještačenja ${ }^{5}$. U drugim se radovima kao snažni prediktori često ističu dijagnoze psihoorganskih poremećaja, kao i mentalne retardacije ${ }^{31}$. Kao što je rečeno, dijagnoza nije ekvivalent raspravnoj nesposobnosti, što govore i podatci Warrena i suradnika iz 2006. godine koji pokazuju da je $63 \%$ okrivljenika sa psihotičnim poremećajem bilo raspravno sposobno, kao i $70 \%$ okrivljenika koji boluju od intelektualne onesposobljenosti (u MKB-10 „mentalne retardacije”) i ostalih intelektualnih poremećaja ${ }^{32}$.

\section{Kognitivna oštećenja}

Neki od čestih razloga koji se vežu za raspravnu nesposobnost različiti su stupnjevi intelektualne onesposobljenosti ili dementna stanja koja zahvaćaju funkcije važne za razumijevanje sudskog postupa - poput orijentacije, pamćenja, apstraktnog mišljenja, koncentracije, računanja i ostalih složenih izvršnih funkcija ${ }^{19}$. Ispod prosječne kognitivne funkcije smatraju se jednim od glavnih razloga raspravne nesposobnosti ${ }^{20}$.

White, Meares i Batherol su 2014. godine u svom sistemskom preglednom radu prikazali značajne korelacije različitih kognitivnih oštećenja $s$ ra- 
spravnom nesposobnošću. Osim inteligencije, raspravno sposobnu od grupe raspravno nesposobnih ispitanika razlikuju bolje verbalno pamćenje, veća brzina procesuiranja informacija i bolje vizuospacijalne vještine ${ }^{21}$. $U$ istom su radu istaknuli očuvanu verbalnu inteligenciju kao onu od posebnog značaja za održanu raspravnu sposobnost. Raspravna nesposobnost koja je definitivnog i trajnog karaktera, iako rjeđa, kada se proglasi, najčešće je vezana uz niži stupanj inteligencije i uz progresivna kognitivna oštećenja, odnosno uz ona stanja za koje se ne očekuje poboljšanje ${ }^{22}$. Ukoliko sud naloži kombinirano psihijatrijsko-psihologijsko vještačenje, psiholog standardiziranim testovima procjenjuje kognitivne sposobnosti ispitanika, napose inteligencije. Uz to, često se koriste i testovi ličnosti i projektivni testovi. lako je vještačenje u ovom slučaju kombinirano, u Hrvatskoj posljednju odluku ipak donosi psihijatar vještak.

\section{Poremećaji raspoloženja}

Poremećaji raspoloženja poput depresije ili manije također mogu utjecati na raspravnu sposobnost, naročito ako u depresivnim poremećajima dominiraju snažniji intenziteti psihopatoloških fenomena poput anhedonije, abulije ili samodestruktivnog ponašanja ${ }^{18}$. Jacobs, Ryba i Zapf u svojem su istraživanju 2008. godine pronašli značajnu korelaciju između raspravne nesposobnosti i manične epizode u sklopu bipolarnog afektivnog poremećaja. Uzbuđenost, napetost, povišeno raspoloženje, motorička hiperaktivnost i distraktibilnost čine klaster od pet simptoma vezanih uz maniju, a koji izraženi u većoj mjeri otežavaju sposobnost shvaćanja pravno značajnih informacija, a naročito otežavaju suradnju s braniteljem kako tijekom dijeljenja informacija tako i pri planiranju obrane. Koristeći Kratku psihijatrijsku ljestvicu (engl. Brief Psychiatric Rating Scale) Lee, Rosner i Harmon ${ }^{24}$ pronašli su korelaciju između „poremećaja misaonog tijeka” i „neobičnih misaonih sadržaja" s raspravnom nesposobnošću i poveznicu s „neprijateljskim osjećajima sumnjičavosti” čime se ponovno naglasila snažnija prediktivna vrijednost određenih psihijatrijskih simptoma u odnosu na psihijatrijsku dijagnozu, što su pokazala i druga istraživanja ${ }^{25}$.

\section{Sumanutosti}

Paranoidna fenomenologija u sklopu psihotičnih poremećaja mogući je razlog raspravne nesposobnosti ${ }^{26}$. Pri svakom vještačenju nužno je procijeniti koliko su zadovoljeni ključni aspekti suradnje sa sudionicima u sudskom postupku, pogotovo s braniteljem s kojim je nužno ostvariti prikladan odnos i suradnju. Kvalitativni poremećaji mišljenja okrivljenika mogu alterirati od značajnih psihotičnih distorzija (branitelj surađuje s

Tijekom vještačenja raspravne sposobnosti ispituje se je li okrivljenik sposoban shvatiti prirodu i svrhu kaznenog postupka, razumjeti pojedine procesne radnje i njihove posljedice, sporazumijevati se $s$ braniteljem i dati mu upute.

Prisutnost bilo koje duševne bolesti neovisno o specifičnostima psihopatologije ne podrazumijeva odmah i raspravnu nesposobnost.

inozemnom tajnom službom) do manje bizarnih (branitelj surađuje sa žrtvinom obitelji). Ukoliko je sumanuti sadržaj intaktan i usmjeren na osobe ili pojave izvan sudskog procesa i njegovih sudionika, okrivljenik je načelno raspravno sposoban. Međutim, moguće je da sudionici ili neki drugi aspekti sudskog postupka postanu integrirani u mrežu sumanutih ideja, čime aktualna raspravna sposobnost postaje isključena ${ }^{27}$.

\section{Poremećaji ličnosti}

Poremećaji ličnosti obično ne predviđaju ishod vještačenja kojim bi se okrivljenika proglasilo raspravno nesposobnim ${ }^{28}$. Budući da se takvi poremećaji dijagnosticiraju prepoznavanjem onih ponašanja i emocionalnih stanja koja se nalaze na ekstremima kontinuuma normalnog ponašanja, psihijatri ih najčešće ne smatraju dovoljnima per se da bi mogli kompromitirati raspravnu sposobnost. Reisner i Piel 2018. u svome su radu opisali kazneni postupak Ohio v Halder iz 2003. godine, a vezan uz problematiku poremećaja ličnosti i definiranja raspravne nesposobnosti općenito ${ }^{29}$. Okrivljenik je u anamnezi imao dijagnozu poremećaja ličnosti, distimije i depresije. Tijekom vje- 
štačenja dva su vještaka donijela ocjenu kako je okrivljenik raspravno nesposoban, dok je treći vještak, čije je mišljenje na kraju i uvaženo, donio ocjenu o očuvanoj raspravnoj sposobnosti. Tijekom ispitivanja trećeg vještaka u žalbenom postupku, branitelj je inzistirao na kriterijima po kojima je donesena ocjena o raspravnoj nesposobnosti. Vještak je kao jedan od kriterija kojim se vodio spomenuo postojanje mentalnog poremećaja ili bolesti, što u tom trenutku u Ohiou nije bio legalan kriterij za vještačenje raspravne sposobnosti nego ubrojivosti. Kao rezultat ovog slučaja, u diskursu položaja poremećaja ličnosti u vještačenju raspravne sposobnosti otvorena je mogućnost da i teži poremećaj ličnosti bude opravdan razlog za raspravnu nesposobnost. U smjernicama Američke akademije psihijatrije i prava iz 2017. istaknut je primjer kaznenog postupka Hayden v Commonwealth 1978. u kojem je okrivljenik evaluiran i dijagnosticiran mu je shizoidni poremećaj ličnosti ${ }^{3}$. lako ocijenjen kao raspravno sposoban, vještak upozorava na mogućnost psihotične dekompenzacije okrivljenika za vrijeme rasprave i stoga je uputa bila da okrivljenik može sudjelovati u vrlo konkretnim postupcima u kojima sudionici koriste izrazito jednostavne fraze i iznose jednostavne ideje. Ovdje valja napomenuti kako za shizoidni poremećaj ličnosti nisu tipične psihotične dekompenzacije, stoga naglašavamo kako se ovdje ističe prije svega forenzičko značenje poremećaja ličnosti u procjeni raspravne sposobnosti za ovaj konkretan slučaj. Zaključno, raspravna sposobnost podrazumijeva da okrivljenik ima dovoljan, ali ne nužno i „savršen” stupanj kapaciteta za razborito shvaćanje potrebno za odvijanje glavne rasprave ${ }^{30}$, stoga nije neobično ni u ekspertizama vještaka u Hrvatskoj pronaći slične preporuke poput češćih stanki i upozorenja na moguća pogoršanja psihičkog stanja.

\section{Amnezije}

U literaturi su amnezije jedan od fenomena koji se može povezati s raspravnom nesposobnošću. Roesch i Golding važnim za forenzičku praksu ističu nekoliko prototipova amnezije ${ }^{33}$. Navode se slučajevi amnezije koji se mogu povezati s traumom glave, zatim s psihodinamskim mehanizmi- ma potiskivanja i disocijativnim fenomenima, odvojeno ili u sklopu poremećaja ličnosti. Jedan je prototip i nastanak amnezije zbog prethodno unesenog alkohola i drugih psihoaktivnih tvari. Amnezija može nastati i zbog egzarcebacije prethodno egzistirajućih somatskih stanja (npr. hipoglikemijske krize) koja mogu dovesti do amnestičkih ili disocijativnih fenomena. Vezano za amneziju, stav je sudskih praktičara ambivalentan. Dio sudaca u anglosaksonskom pravu zagovara Wilsonove kriterije koji naglašavaju važnost očuvanog sjećanja vezanog uz djelo kako bi suradnja s braniteljem bila adekvatna. Drugi se pak dio čvrsto drži Duskyevih kriterija i ne smatra amneziju ni na koji način kompromitirajućim čimbenikom u aktualnoj raspravi kad je očuvano racionalno i faktičko razumijevanje postupka, kao i sporazumijevanje s braniteljem ${ }^{33}$. Goreta i suradnici u svojoj zbirci ekspertiza naglašavaju važnost analiziranja popratne dokumentacije koja može ukazivati na očuvano pamćenje i neko vrijeme nakon djela, a koje okrivljenik u vrijeme vještačenja može demantirati. Takvo što se može objasniti eventualno organskim zbivanjima, a nikako u sklopu kakve druge psihopatologije ${ }^{34}$. Isto tako, hrvatski ZKP indirektno otklanja mogućnost amnezije kao opravdanog razloga za raspravnu nesposobnost. Konkretno, vještak se prilikom procjene aktualnog duševnog stanja ispitanika ne upliće u sadržaj obrane koji će ispitanik dogovarati s braniteljem, nego je zadaća vještaka procijeniti može li se ispitanik "sporazumijevati s braniteljem i davati mu upute”, pa tako amnezija ne bi trebala biti relevantan čimbenik u vještačenju raspravne sposobnosti.

\section{Simulacija raspravne nesposobnosti}

Raspravna sposobnost može biti privremeno isključena unatoč prepoznatim simulacijskim elementima ako se uz njih prepoznaju i drugi teži poremećaji. Preporuka je dopustiti pacijentu da se neko vrijeme prilagodi novonastaloj situaciji, izbjeći etiketiranje koje može potaknuti dublje regresivne mehanizme i dodatni pad motivacije ${ }^{35}$. U složenim slučajevima može se pojaviti potreba za prisutnošću vještaka tijekom cijele glavne rasprave ne bi li u bilo kojem trenutku vještak mogao dati svoje mišljenje o aktualnom psihičkom 
stanju okrivljenika ${ }^{33}$. U nekim slučajevima kada, primjerice, okrivljenik odbija bilo kakvu suradnju u vidu mutističnog ponašanja s vještakom, važno je proučiti što recentniju medicinsku dokumentaciju s ciljem bolje procjene eventualne simulacije i sekundarne dobiti ${ }^{34}$.

\section{ZAKLJUČAK}

Jedno od temeljnih ljudskih prava - pravo na pošteno suđenje, nemoguće je uživati ukoliko okrivljenik nema uvid u svoj položaj za vrijeme sudskog postupka, ako nema dovoljne kapacitete za razumijevanje sudskog procesa i nije u mogućnosti sporazumijevati se s braniteljem i davati mu upute. Razumljivo je da žrtve, ali i cjelokupno društvo traže kaznu i svojevrsno iskupljenje za počinjena protupravna djela, međutim duševno bolesni okrivljenici koji nisu raspravno sposobni stavljeni su u nepovoljan položaj u kojem se nisu sposobni braniti i time su dignitet sudskog procesa i svrhovitost kazne narušeni. Cilj ovoga rada bio je približiti važnost razumijevanja raspravne sposobnosti unutar forenzične psihijatrije. Naglasak je i na čuvanju temeljnih ljudskih prava osoba koje društvo često odbaci, a koji zbog svoga stanja nerijetko budu stigmatizirani i od zdravstvenog sustava i njegovih izvršitelja. No, doseg današnjeg civilizacijskog napretka jest i u tome što se tim osobama pristupa s kritičkog medicinskog stajališta. lako nije nezamislivo kako laici takvo što još uvijek vide više kao naklonjenost okrivljeniku, vještak bi trebao staviti svoju stručnost u službu zaštite čovjekova dostojanstva i autonomije i na taj način sudjelovati u čuvanju ravnopravnog položaja duševnih bolesnika tijekom sudskog postupka.

Izjava o sukobu interesa: Autori izjavljuju kako ne postoji sukob interesa.

\section{LITERATURA}

1. Grozdanić V. Pravni sadržaj forenzičke psihijatrije. U: Kozarić-Kovačić D, Grubišić-llić $M$, Grozdanić V (ur). Forenzička psihijatrija. Zagreb: Medicinska naklada, 2005;9-54.

2. Zapf PA, Roesch R. Best practices in forensic mental health assessment: Evaluation of competence to stand trial. $1^{\text {st }}$ Edition. New York: Oxford University Press, 2009;224.

3. Mossman D, Noffsinger SG, Ash P, Frierson RL, Gerbasi J, Hackett M i sur. AAPL practice guideline for the forensic psychiatric evaluation of competence to stand trial. J Am Acad Psychiatry Law 2007;35:3-72.

4. Hoge SK. Compentence to stand trial: An overview. Indian J Psychiatry 2016;58:187-90.

5. Pirelli G, Gottdiener WH, Zapf PA. A meta-analytic review of competency to stand trial research. Psychol Public Policy Law 2011;17:1-53.

6. Favole RJ. Mental disability in the American criminal process: A four issue survey. In: Monahan J, Steadman HJ (eds). Mentally disordered offenders: Perspectives from law and social science. New York: Wiley, 1983; 247-295.

7. Zakon o kaznenom postupku (Narodne novine, br. 76/09, 143/12, 145/13).

8. Council of Europe [Internet]. Strasbourg: European Convention of Human Rights [cited 2020 Nov 7]. Available from: Dostupno na: https://www.echr.coe.int/ documents/convention_eng.pdf.

9. Van Koppen PJ, Penrod SD. Adversarial or inquisitorial. Comparing systems. In: Van Koppen P J, Penrod SD (eds). Adversarial versus inquisitorial justice: Psychological perspectives on criminal justice systems. New York: Kluwer Academic, 2003;1-19.

10. Bonnie Rj, Grisso T. Adjudicative competence and youthful offenders. In: Grisso T, Schwartz RG (eds). Youth on Trial: A Developmental Perspective on Juvenile Justice. Chicago: University of Chicago Press, 2000;73-103.

11. McGarry AL. Competence to stand trial and due process via the state hospital. Am J Psychiatry 1965;128:105-9.

12. van der Wolf $M$, van Marle $H$, Mevis $P$, Roesch R. Understanding and evaluating contrasting unfitness to stand trial practices: A comparison between Canada and the Netherlands. Int J Forensic Ment Health 2010;9:245-258.

13. Kazneni zakon (Narodne novine, br. 125).

14. Johnston EL. Vulnerability and just desert: A theory of sentencing and mental illness. J Crim Law Criminol 2013;103:147-192.

15. Mester R, Gonen N. Asking questions about competence to stand trial. J Forens Psychiatry 1992;3:551-557.

16. Goreta M. Errare humanum est: Najčešće pogreške u forenzičko-psihijatrijskoj praksi. 1. izdanje. Zagreb: Naklada Slap, 2015;6-23.

17. Folnegović-Šmalc $V$, Henigsber N, Folnegović-Grošić $P$. Vještačenje sposobnosti sudjelovanja u sudskom procesu. U: Žarković Palijan T, Kovačević D (eds). Forenzička psihijatrija 2. Zagreb: Naklada Ceres, 2007;77-88.

18. Resnick PJ, Noffsinger S. Competency to Stand Trial and Insanity Defense. In: Simon RI, Gold LH (eds). The American Psychiatric Publishing Textbook of Forensic Psychiatry. Washington: American Psychiatric Pub, 2004;597.

19. Frierson RL, Shea SJ, Craig Shea ME. Competence-toStand-Trial Evaluations of Geriatric Defendants. J Am Acad Psychiatry Law 2002;30:252-6.

20. Pirelli G, Zapf PA, Gottdiener WH. Competency to stand trial research: Guidelines and future directions. J Forens Psychiatry Psychol 2011;1-31.

21. White AJ, Meares S, Batchelor J. The role of cognition in fitness to stand trial: a systematic review. J Am Acad Psychiatry Law 2014;25:1.

22. Colwell LH, Gianesini J. Demographic, criminogenic, and psychiatric factors that predict competency restoration. J Am Acad Psychiatry Law 2011;39. 
23. Jacobs MS, Ryba NL, Zapf PA. Competence-Related Abilities and Psychiatric Symptoms: An Analysis of the Underlying Structure and Correlates of the MacCAT-CA and the BPRS. Law Hum Behav 2008;32:64-77.

24. Lee E, Rosner R, Harmon R. Mental illness and legal fitness (competence) to stand trial in New York State: Expert opinion and criminal defendants' psychiatric symptoms. J Forensic Sci 2014;59.

25. Gay JG, Vitacco MJ, Ragatz L. Mental health symptoms predict competency to stand trial and competency restoration success. Legal Criminol Psych 2017;22:288-301.

26. Goldstein RL. Paranoids in the legal system: The litigious paranoid and the paranoid criminal. Psychiatric Clinics 1995;18:303-315.

27. Noonan JR. Competency to stand trial and the paranoid spectrum. Am J Forensic Psychol 1999;17:5-27.

28. Ciccone JR. Competence to stand trial and psychopathic disorders: Legal and clinical perspectives from the USA. In: Felthous AR, Saß H (eds). International handbook on psychopathic disorders and the law. New Jersey: John Wiley \& Sons, 2008;189-200.
29. Reisner AD, Piel JL.Mental Condition Requirement in Competency to Stand Trial Assessments. J Am Acad Psychiatry Law 2018;46:86-92.

30. Melton GB, Petrila J, Poythress NG, Slobogin C. Competency to stand trial. In: Melton GB, Petrila J, Poythress NG et al. (eds). Psychological Evaluations for the Courts: A Handbook for Mental Health Professionals and Lawyers. New York: Guilford, 2007;930.

31. Warren JI, Murrie DC, Stejskal W, Colwell LH, Morris J, Chauhan $\mathrm{P}$ et al. Opinion formation in evaluating the adjudicative competence and restorability of criminal defendants: A review of 8,000 evaluations. Behav Sci Law 2006;24:113-132.

32. Roesch R, Golding S. Amnesia and competency to stand trial: A review of legal and clinical issues. Behav Sci Law 1986;4:87-97.

33. Goreta $M$, Bojić $M$. Psihijatrijska vještačenja. 3. izdanje. Zagreb: Medicinska naklada, 2015;1204.

34. Goreta M. Raspravna sposobnost. U: Goreta M, PekoČović I, Buzina N. (ur). Psihijatrijska vještačenja, zbirka ekspertiza. Zagreb: Naklada Zadro, 2004;717. 